\title{
The Impact of Transformational Leadership on Employees' Organizational Commitment in Egyptian Airlines
}

\author{
Marwa A. Atia* Toka M. Fahmy* * Hamida A. Mohammed \\ *Faculty of Tourism and Hotels, University of Sadat City
}

\begin{abstract}
Organizational commitment is considered one of the most important phenomena in business organizations. As a result, there was a need to study human behavior in organizations with a view to stimulate and increase its commitment. Leadership is one of the most important phenomena of social interaction. The style of Transformational Leadership is considered one of the latest styles of leadership known in Egypt. Managers and organizations in tourism and hospitality industry face real challenges in recruiting, developing and maintaining a committed, competent, well managed teamwork, So that the goal of this study was to study the relationship between transformational leadership and organizational commitment in civil aviation industry.

The importance of research is to recognize the importance of the role played by the transformational leader on organizational commitment to the employees. The results indicated that there is a significant correlation between the transformational leadership style and the employees' organizational commitment. Aviation industry is considered as a part of tourism and hospitality industry which plays a vital role in the economic development of many countries, and Egypt is no exception. Tourism and hospitality industry as a whole in Egypt has become a major player in stimulating economic growth and providing more jobs. It helps also in promoting economic development through its interrelationships with other economic sectors.
\end{abstract}

Key words: Transformational Leadership, Organizational Commitment, Airlines, Egypt.

\section{Literature Review}

\subsection{The Transformational Leadership}

Over the past two decades, transformational leadership has emerged as one of the most popular approaches to understanding leader effectiveness (Sharma et al., 2012). The primary focus of this leadership style is to make change happen (El Gamal, 2009). Transformational leaders motivate others, set higher and more challenging goals, act as role models, and are trustworthy and ethical (Stokes, 2013; Nahavandi, 2016).

\subsubsection{Theory of Transformational Leadership}

Transformational leadership idea was first developed by Burns (1978) and later extended by Bass (1985). Transformational leadership involves inspiring followers to commit a shared vision and goals for an organization, challenging them to become innovative problem solvers, and developing followers' leadership capacity (Indrawat, 2014; Ebrahimi et al., 2016; Nahavandi, 2016). 
Transformational leadership centers in the leader's ability to build trust, loyalty, and admiration in followers (Freiberg, 1987; Chatterjee \& Kulakli, 2015). Transformational leadership has been recognized as a powerful model of leadership (Wahab et al., 2016). It simulates people to do more than what is expected (Aliakbari \& Darabi, 2013; Nahavandi, 2016).

Recently, transformational leadership theory has received a great amount of attention and has been considered as one of the most controlling leadership theories (Banks et al., 2016; Nahavandi, 2016).

Bass \& Avolio (1994) found that transformational leadership involves a change of employees' beliefs, values and attitudes. Therefore this type of leadership will inspire and motivate followers to achieve more than originally thought possible (Longwell-McKean, 2012; Rothfelder et al., 2012; Nahavandi, 2016).

\subsubsection{Defining transformational leadership}

Transformational leadership is defined as "the ability to motivate followers to perform beyond what he/she would normally expect" (Bass, 1985: cited in Mohamed, 2016: 50; Bass, 1985: cited in Stokes, 2013: 36). Transformational leadership can also be defined as "a leadership style that enhances subordinates' awareness of the importance of task outcomes, inspires higher-order needs, and motivates subordinates to transcend self-interests for the sake of the organization" (Chao et al., 2016: 10).

\subsubsection{Dimensions of transformational leadership}

Bass (1985) conceptualized transformational leadership as having four dimensions, namely idealized influence, intellectual stimulation, inspirational motivation and individualized consideration (Nahavandi, 2016). Bass \& Avolio (1994) characterized transformational leadership as being composed of four unique but interrelated behavioral components: (Jung et al., 2003). Using these constructs, Bass developed the Multifactor Leadership Questionnaire (MLQ), which was used to measure the four domains of transformational leadership. These four domains of transformational leadership are described in the following sections:

\section{- Inspirational Motivation}

Inspirational motivation refers to the degree to which leaders are able to provide followers with a sense of motivation in their job that will generate additional goal-directed energy for the organization (El mrad, 2005; Zhu et al., 2013). They do this by creating a new vision, mobilizing commitment to that vision, setting clear strategies for achieving the vision, and communicating these clearly to followers (Zhu et al., 2013).

Also, inspirational motivation refers to the leader's ability to inspire and motivate followers through providing meaning and challenge to their work, communicate expectations to them and demonstrate commitment to goals and the shared vision (Liu, 2013). The leader who seeks to motivate will inspire such behavior by communicating high expectations and will convince his 
followers that they have the ability to achieve levels beyond the possible (Longwell-McKean, 2012). Transformational leaders motivate followers by getting them invested in the organization's goals as well as developing expectations and communicating them in an inspiring manner (Jacob, 2015).

\section{- Idealized Influence}

Idealized Influence is a transformational leadership dimension that refers to leaders who encouraged followers to share their aims, targets, visions and goals (Sharma et al., 2012). "Idealized influence can be defined as the key element of transformational leadership that lets leaders be the behavior and role models for employee in following values and believes" (Allameh \& Davoodi, 2011: 3132). It causes leaders to be role models for their employees(Allameh \& Davoodi, 2011). Within idealized influence leaders guide followers to trust, imitate, like, admire, and resemble with them (Chao et al., 2016). Leaders with higher levels of idealized influence can create greater trust, loyalty, and respect from followers (Jacob, 2015).

\section{- Individualized Consideration}

Individualized consideration is the degree to which leaders attend to followers' needs, act as mentors or coaches, and listen to followers' concerns (Colquitt, 2006). Individualized consideration is considered leaders interest in professional and individual development for their subordinates (Allameh \& Davoodi, 2011), and it occurs when leaders respect their followers, when also they acknowledge individual differences among them, and when leaders act in a way that is interested in follower satisfaction so much (Stokes, 2013; Yates, 2013).

In individual consideration leaders show concern for the prosperity of each person they work with; treating each one as an individual with unique needs and abilities; placing a considerable personal amount of attention, personal advice, and opportunities to develop for each person according to his / her potential (Liu, 2013). Therefore, Leaders act like a coach to each follower and admit personal differences among followers (Stokes, 2013). There is an establishment of a supportive climate where individual differences are respected (Cetin \& Kinik, 2015). So that, leaders should know each follower very well (Baek, 2012).

\section{- Intellectual Stimulation}

Intellectual stimulation is a characteristic in which, the leader provides an environment that is suitable for developing problem solving skills, creativity, and independent thought (Yates, 2013). Intellectual stimulation occurs when the leader takes an approach to help followers think creatively when solving problems (Stokes, 2013). Intellectual stimulation is seen as framing and reframing problems, questioning assumptions and stimulating followers to creative thinking and innovation (Liu, 2013).

The importance of intellectual stimulation comes as the leader is confronted with ill-structured problem as opposed to well-structured problems (Jacob, 2015). 
Intellectual Stimulation has an important role in the transformation process of the organization (Jacob, 2015). Through intellectual stimulation, transformational leaders encourage their followers to use nontraditional thinking to deal with traditional problems (Sharma et al., 2012; Nahavandi, 2016).

\subsection{Organizational Commitment}

\subsubsection{Defining Organizational Commitment}

There are many different definitions of organizational commitment which have been discussed from different researchers:

A strong belief in and admission of the organizational goals, to exert effort on behalf of the organization and a desire to maintain organizational membership (Afşar, 2014). The willingness of an employee to be a member of an organization and not to complain about this organization (Ahmad et al., 2014).

In sum, Bozlagan et al. 2010 lists some of the organizational commitment benefits:

1. It raises job satisfaction, performance of employees and of organization as a whole.

2. It improves organizational atmosphere and changing in positive way.

3. It reduces tardiness, dismissals, job stress and the turnover rate.

4. It helps employees to adopt "organizational loyalty" behavior.

5. It enhances trust, cooperation and consistency between employees.

\subsubsection{Meyer and Allen's model of organizational commitment}

Meyer and Allen's model of organizational commitment is based on the multidimensional nature of organizational commitment (Lumley et al., 2008).

A- Affective commitment

Affective commitment encompasses the employee's emotional attachment to and participation in the organization and its goals (Meyer \& Allen, 1997; Seppänen, 2012). As a result, affective commitment is more difficult to reach, compared with the other two types of organizational commitment, because it is linked to and associated with organizational values such as high motivation towards better organizational effectiveness and high levels of job satisfaction (Gandhi \& Hyde, 2013).

\section{B- Continuance commitment}

Continuance Commitment encompasses commitment based on the costs that individual associates with leaving the organization (Lumley et al., 2008; Qassem, 2012; Gandhi \& Hyde, 2013). An individual's investment in the organization has a great influence on individuals' level of continuance commitment (Gandhi \& Hyde, 2013). Thus, there are two factors that affect an individual's level of continuance commitment. These factors are; - a) the individual sacrifices of losing his investments in the organization, b) to which extent the individual has alternatives outside the organization if he quit his job (Anttila, 2014). 
C- Normative commitment

Normative Commitment is different from the other two types of commitment, because the employee beliefs that it is some kind of responsibility to stay in the organization (Gandhi \& Hyde, 2013). Meyer and Allen (1997) found that normative commitment ties with the employee's feelings, who feel an obligation to remain in the organization primarily because of the pressures from others. It is suggested that normative commitment is determined by the individual's experiences both before and after entering the organization (Meyer \& Allen, 1991; Khan et al., 2013; Anttila, 2014).

\subsection{Transformational Leadership and Organizational Commitment}

In recent years, leader's leadership style can affect organizational objectives, organizational commitment and also organizational performance. Thus, leadership style is very important to motivate employees' commitment to fulfill organizational objectives and increase job performance (Madi et al., 2012; Irefin \& Mechanic 2014).

As indicated by many researchers, transformational leadership behaviors have more influence on the organizational commitment. There are many studies that confirm that leaders' transformational behaviors jointly played significant role in organizational commitment of employees (Naktiyok \& Yekeler, 2016; Triana et al., 2016).

Kala'lembang et al. (2015) found that there is a direct effect which has a positive and significant correlation between transformational leadership on organizational commitment. Jong Hun (2012) proved that transformational leadership behaviors have statistically significant influence on organizational commitment. Rehman et al. (2012) showed that transformational leadership has positive relationship with the organizational commitment.

The power of transformational leadership will increase employees' organizational commitment; which can be seen from the attitude of loyal employees (Bill, 2010; Kala'lembang, et al. 2015). Gulluce et al. (2016) clarified that a leader with transformational leadership behaviors aims to transform, encourage and inspire his/her followers for them to perform better than expected. Thus, this way of leadership leads to an increase in organizational commitment of employees. Employees are far more likely to be committed to the organization if they have confidence with their leaders (Gulluce, et al. 2016).

Contractor (2016) found that transformational leadership is at the core of organizational commitment, and transformational leaders are better able to enhance the organizational commitment of the Employees (Contractor, 2016).

\section{Methodology}

Methodology presents the study design that is a strategy for gathering evidence about the knowledge desired for checking research hypothesis (De Vos et al, 2005). The main aim of the study is to investigate the relationship between transformational leadership and organizational commitment in Egyptian airlines. 
Therefore, in order to achieve that goal the recent study aimed to achieve the following objectives: A) Identify the theory of transformational leadership, definitions and dimensions of transformational leadership. B) Determine the definitions, types and dimensions of organizational commitment. C) Identify the relationship between transformational leadership and organizational commitment. D) Set some recommendations for decision maker and also for researchers that can guide them.

\subsection{Hypotheses of the study}

There is a significant relationship between transformational leadership and organizational commitment in airline companies.

\subsection{Research Instrument}

The study employed a questionnaire as an instrument for data collection (Zikmund, 2003). When developing questionnaire, items or questions that require the respondent to respond to a series of questions or statements. Participants' responses are then converted into numerical form and statistically analyzed (Bowling, 1997).

Questionnaire form being used in the study composed of three sections to facilitate the data analysis process: The first section was about the demographics of the respondents and other work related information, the second section measures the perceived level of transformational leadership, finally, the third section that determines employee's perception of organizational commitment.

\subsection{Measurement}

To achieve the study objectives the researcher used two scale measurements The Multifactor Leadership Questionnaire and The Organizational Commitment Scale. The Multifactor Leadership Questionnaire measures transformational leadership styles (Avolio \& Bass, 2004). The researcher chose the MLQ because of its ability to determine transformational leadership and its high validity and reliability. The Scale is a 20-item, four-factor model (Idealized influence 8 items- Inspirational motivation 4 items - Intellectual stimulation 4 items - Individual consideration 4 items) (Avolio \& Bass, 2004).

The Organizational Commitment Scale was originally designed, developed, and validated by Buchanan (1974). The Organizational commitment Scale is a 24-item, three-factor model (Affective Commitment 8 items - Continuance Commitment 8 items - Normative Commitment 8 items) (Allen \& Meyer 1990).

\subsection{Pretest and Pilot Study of the Measurement Instrument}

The questionnaire was initially pre-tested for its validity and reliability before final administration. A number of survey forms (20 forms) were distributed to some airline employees at two airline companies and professors at tourism studies department at the faculty of tourism and hotels, University of Sadat City to get feedback regarding accuracy of questions instrument. 
For study scale, the Cronbach's alpha reliability was computed and the test showed that the reliability coefficients for study scale were above 0.60 that indicate that the instrument is reliable for being used. For this study, Cronbach alpha for survey instrument presented was calculated for the Multifactor Leadership Questionnaire, and the Organizational Commitment Scale in table (1).

Table (1) Cronbach alpha for study instrument

\begin{tabular}{|c|l|c|c|c|}
\hline No. & \multicolumn{1}{|c|}{ Study Scale } & $\begin{array}{c}\text { Number of } \\
\text { items }\end{array}$ & Alpha & $\begin{array}{c}\text { Validity } \\
\text { factor }\end{array}$ \\
\hline 1 & Transformational leadership scale & 20 & .838 & 0.915 \\
\hline 2 & organizational commitment scale & 24 & .888 & 0.942 \\
\hline 3 & The overall scale & 60 & .813 & 0.902 \\
\hline
\end{tabular}

Table (1) shows that the value of alpha- Cronbach and Validity factors range are between (0.813) and (0.902). These values are acceptable in a way that reflects the availability of reliability and confidence in the study variables.

\subsection{Study Sample}

According to the annual bulletin of air transport statistics (2015) issued by The Central Agency for Public Mobilization and Statistics (CAPMAS) there are about 21 national airline companies and about 34075 employee.

The study was applied on the employees including all functional categories.

A convenience sample of those employees was chosen for investigation. This sampling method involves getting participants wherever you can find them and typically wherever is convenient (Kowalczyk, 2015). According to Veal (2006), the study sample for the population that is about 34075 is about (381) questionnaire.

The questionnaire forms were distributed to employees (450 printed form were distributed as one questionnaire for each one, in addition to the link of Google form was sent to other respondents). The questionnaire forms were distributed among all categories of employees at Egyptian airline companies. A total 438 forms were received, 407 questionnaires were deemed valid, while 31 questionnaires from the printed copies were invalid.

\subsection{Data Collection}

All the questionnaire forms were distributed from March to June 2017. The researcher used another source in order to capture as possible responses from target population. They were asked to fill the questionnaire through the following questionnaire link on Google Forms.

https://docs.google.com/forms/d/1b8jtGvB5TnBnWwYNryDRo-

1EMLgIRGNfiJOaTrXPQ0M/edit?usp=forms_home

\subsection{Data Analysis}

The Statistical Package for the Social Sciences (SPSS) for windows v.16.0 was used to analyze the data collected, the analyze include the following statistical methods: 
1. Frequencies, Percentage, Mean value and Standard deviation to describe characteristics of study sample and measure the respondent's answers in part two and part three.

2. Pearson Correlation Coefficient was used to show relation between study variables and verifying hypotheses.

3. A multiple regression analysis was conducted to evaluate the effect of organizational commitment on the transformational leadership style. In this type of multiple regressions, the independent variable is entered, evaluated and assessed in relationship to the dependent variable (Tabachnick \& Fidell, 2007).

\section{Results and Discussion}

This section includes results of the statistically processes tested on study's sample and questions. Moreover, find out the statistically significance level for results to characterize the impact of transformational leadership on employees' organizational commitment in Egyptian airlines.

\subsection{Demographic profile of Survey Respondents}

The questionnaire used for this study included seven items concerning the employees demographic characteristics, the employees were asked about their company name, job title, marital status, educational level, gender, age, and their Years of Employment. This information was useful in understanding background of respondents. Results are presented in table (2)

Table (2) Demographic profile of Survey Respondents

\begin{tabular}{|c|c|c|c|c|c|}
\hline $\mathbf{N}$ & $\begin{array}{c}\text { Demographic } \\
\text { information of Survey } \\
\text { Respondents }\end{array}$ & Classes & Freq & $\%$ & $\begin{array}{l}\text { Valid } \\
\text { Percent }\end{array}$ \\
\hline \multirow{4}{*}{1} & \multirow{4}{*}{ marital status } & Single & 102 & 25.1 & 25.1 \\
\hline & & Divorced & 44 & 10.8 & 10.8 \\
\hline & & Married & 261 & 64.1 & 64.1 \\
\hline & & Total & 407 & $100 \%$ & 100 \\
\hline \multirow{5}{*}{2} & \multirow{5}{*}{ Educational Level } & High School & 47 & 11.5 & 11.5 \\
\hline & & Two year college & 31 & 7.6 & 7.6 \\
\hline & & Four year college & 312 & 76.7 & 76.7 \\
\hline & & $\begin{array}{c}\text { Master-Doctorate } \\
\text { degree }\end{array}$ & 17 & 4.2 & 4.2 \\
\hline & & Total & 407 & $100 \%$ & 100 \\
\hline \multirow{3}{*}{3} & \multirow{3}{*}{ Gender } & Male & 303 & 74.4 & 74.4 \\
\hline & & Female & 104 & 25.6 & 25.6 \\
\hline & & Total & 407 & $100 \%$ & 100 \\
\hline \multirow{5}{*}{4} & \multirow{5}{*}{ Age } & under 30's & 112 & 27.5 & 27.5 \\
\hline & & 30 - under 40 & 161 & 39.6 & 39.6 \\
\hline & & 40 - under 50 & 105 & 25.8 & 25.8 \\
\hline & & 50 - over 50 & 29 & 7.1 & 7.1 \\
\hline & & Total & 407 & $100 \%$ & 100 \\
\hline
\end{tabular}




\begin{tabular}{|c|c|c|c|c|c|}
\hline \multirow{4}{*}{5} & under 2 years & 20 & 4.9 & 4.9 \\
\cline { 3 - 6 } & $\begin{array}{c}\text { 2- less than 5 } \\
\text { years }\end{array}$ & 105 & 25.8 & 25.8 \\
\cline { 3 - 6 } & $\begin{array}{c}\text { 5- less than } 10 \\
\text { years }\end{array}$ & 119 & 29.2 & 29.2 \\
\cline { 3 - 6 } & over 10 years & 163 & 40.0 & 40.0 \\
\cline { 3 - 6 } & Total & $\mathbf{4 0 7}$ & $\mathbf{1 0 0 \%}$ & $\mathbf{1 0 0}$ \\
\hline
\end{tabular}

The data in table (2) indicate that high percent of respondents were married that (represented $64.1 \%$ ) followed by single (which represented $25.1 \%$ ) and finally divorced (which represented $10.8 \%$ ). In addition, there is variety of educational levels of respondents as a high percent was for four year college (which represented 76.7\%), then high school (which represented 11.5\%), followed by two year college (which represented 7.6\%), and finally master degree - doctorate degree (which represented 4.2\%). In addition, high percent of respondents were male (which represented $74.4 \%$ ), then female (which represented $25.6 \%$ ).

Also the data indicate that high percent of respondents and years of employment, over 10 years (representing 40.0\%) then 5- less than 10 years (representing 29.2\%) then 2- less than 5 years (representing 25.8\%), followed by under 2 years which represented $(4.9 \%)$.

The data also indicate that high percent of respondents and age ranges, between 30 to less than 40 (representing 39.6\%), then less than 30 (representing 27.5\%), followed by 40 to less than 50 (which represented (25.8\%), then 50 to over than 50 (which represented $7.1 \%$ ).

\subsection{Statistical Descriptive about the study variables:}

Table (3) : Statistical Descriptive of transformational leadership

\begin{tabular}{|c|c|c|c|c|c|c|c|}
\hline \multirow{2}{*}{ Dimension } & \multirow{2}{*}{ Mean } & \multirow{2}{*}{$\mathrm{SD}$} & \multicolumn{6}{|c|}{ Frequencies (\%) } \\
\cline { 5 - 8 } & & 1 & 2 & 3 & 4 & 5 \\
\hline $\begin{array}{c}\text { Idealized } \\
\text { influence }\end{array}$ & 2.818 & 1.17 & 27.675 & 15.25 & 20.55 & 20.7 & 15.819 \\
\hline $\begin{array}{c}\text { Inspirational } \\
\text { motivation }\end{array}$ & 3.168 & 1.21 & 19.225 & 14.425 & $\begin{array}{c}18.62 \\
5\end{array}$ & 25.675 & 22.075 \\
\hline $\begin{array}{c}\text { Intellectual } \\
\text { stimulation }\end{array}$ & 3.56 & 1.10 & 5.65 & 14.625 & 21.45 & 35.45 & 22.875 \\
\hline $\begin{array}{c}\text { Individual } \\
\text { consideration }\end{array}$ & 2.535 & 1.20 & 26.775 & 29.125 & $\begin{array}{c}19.22 \\
5\end{array}$ & 13.575 & 11.325 \\
\hline
\end{tabular}

$* 1$ = strongly Disagree, 2= Disagree, 3=Neutral, 4=Agree, 5= Strongly Agree

According to the data shown in table (3) concerning the dimension of idealized influence, the percentage of overall acceptance was $36.513 \%$. While $20.55 \%$ of the sample marked neutral, the percentage of disagreement was $42.925 \%$. The mean value was 2.8175 and the standard deviation was 1.179 , this means that the overall orientation of the respondents is neutral. 
This means that leaders are quite encourage followers to share their visions and goals. Leaders are sometimes acting as role models for their employees. They occasionally guide followers to trust, admire, and resemble with them. Leaders may demonstrate high standards of ethical conduct and is also highly admired, respected and trusted by their followers

According to the data shown in table (3) concerning the dimension of inspirational motivation, the percentage of overall acceptance was $47.75 \%$. While $18.625 \%$ of the sample marked neutral, the percentage of disagreement was $33.65 \%$. The mean value was 3.168 and the standard deviation was 1.218 , this means that the overall orientation of the respondents is neutral. This means that leaders sometimes are able to provide followers with a sense of motivation in their job that may generate additional goal-directed energy for the organization. That results in, leaders create a new vision, mobilize commitment to that new vision, convince his followers that they have the ability to achieve levels beyond the possible, provide a sense of purpose for goals, set clear strategies for achieving the vision, communicate these clearly to followers, and generate optimism amongst them. Therefore, followers react by willingly increasing their efforts to achieve the common vision.

According to the data shown in table (3) concerning the dimension of intellectual stimulation, the percentage of overall acceptance was $58.325 \%$. While $21.45 \%$ of the sample marked neutral, the percentage of disagreement was $20.275 \%$. The mean value was 3.56 and the standard deviation was 1.109 , this means that the respondents accepted the dimension. This means that the leader provides an environment that is suitable for developing problem solving skills, and creativity. That means that, leaders stimulates subordinate to think creatively and use their imagination.

According to the data shown in table (3) concerning the dimension of individual consideration, the percentage of overall acceptance was $24.91 \%$. While $19.225 \%$ of the sample marked neutral, the percentage of disagreement was $55.9 \%$. The mean value was 2.535 and the standard deviation was 1.207, this means that the respondents disagreed with the dimension.

This may be a result of the leaders feeling responsible about not take their employees opinions in consideration. Leaders do not attend to followers' needs and do not listen to followers' concerns, are not interest in professional and individual development for their subordinates, do not treat each one as an individual with unique needs and abilities and do not consider individual differences.

Table (4): Overall Statistical Descriptive of transformational leadership

\begin{tabular}{|c|c|c|c|c|c|c|c|}
\hline The variable & \multirow{2}{*}{ Mean } & \multirow{2}{*}{ SD } & \multicolumn{5}{|c|}{ Frequencies (\%) } \\
\cline { 4 - 8 } & & $\mathbf{1}$ & $\mathbf{2}$ & $\mathbf{3}$ & $\mathbf{4}$ & $\mathbf{5}$ \\
\hline $\begin{array}{c}\text { Transformationa } \\
\text { 1 leadership }\end{array}$ & 3.02 & 1.17 & 19.83 & 18.35 & 19.94 & 23.85 & 18.024 \\
\hline
\end{tabular}

$* 1$ = strongly Disagree, 2= Disagree, 3=Neutral, 4=Agree, 5= Strongly Agree 
Finally, as shown in table (4) the mean value of the overall variable of transformational leadership variable is (3.02); this value indicates that the respondents were neutral about the variable, which means that, the respondents indicate that their leaders are moderately applying the transformational leadership style.

Table (5) : Statistical Descriptive of organizational commitment

\begin{tabular}{|c|c|c|c|c|c|c|c|}
\hline \multirow{2}{*}{ Dimension } & \multirow{2}{*}{ Mean } & \multirow{2}{*}{ SD } & \multicolumn{5}{|c|}{ Frequencies (\%) } \\
\cline { 4 - 8 } & & & $\mathbf{1}$ & $\mathbf{2}$ & $\mathbf{3}$ & $\mathbf{4}$ & $\mathbf{5}$ \\
\hline Affective Commitment & 2.95 & 1.064 & $\mathbf{1 5 . 0 6}$ & $\mathbf{2 4 . 4 4}$ & $\mathbf{2 4 . 0 1}$ & $\mathbf{2 3 . 8 9}$ & $\mathbf{1 2 . 6}$ \\
\hline Continuance Commitment & 2.918 & 1.248 & $\mathbf{1 8 . 9 4}$ & $\mathbf{2 0 . 9 6}$ & $\mathbf{2 1 . 8}$ & $\mathbf{2 4 . 8 6}$ & $\mathbf{1 3 . 0 5}$ \\
\hline Normative Commitment & 3.068 & 1.194 & $\mathbf{1 6 . 0 9}$ & $\mathbf{1 6}$ & $\mathbf{3 0 . 5}$ & $\mathbf{1 9 . 8 4}$ & $\mathbf{1 7 . 5 8}$ \\
\hline
\end{tabular}

$* 1$ = strongly Disagree, 2= Disagree, 3=Neutral, 4=Agree, 5= Strongly Agree

According to the data shown in table (5) concerning the dimension of affective commitment, the percentage of overall acceptance was $36.49 \%$. While $24.01 \%$ of the sample marked neutral, the percentage of disagreement was $39.5 \%$. The mean value was 2.95 and the standard deviation was 1.064 . This means that the respondents were neutral about the dimension. This means that, the employees are sometimes become more involved and recognize the value of their identity from association with the organization.

They occasionally believe in the organization's goals and values and feel they are familiar with the organization and its principles. According to the data shown in table (5) concerning the dimension of continuance commitment, the percentage of overall acceptance was $37.91 \%$. While $21.8 \%$ of the sample marked neutral, the percentage of disagreement was $39.9 \%$. The mean value was 2.918 and the standard deviation was 1.248. This means that the respondents disagreed with the dimension. This may be a result of the employee is aware of the costs and threats linked to leaving the organization.

According to the data shown in table (5) concerning the dimension of normative commitment, the percentage of overall acceptance was $37.42 \%$. While $30.5 \%$ of the sample marked neutral, the percentage of disagreement was $32.09 \%$. The mean value was 3.068 and the standard deviation was 1.194 , this means that the respondents accepted the statement. This may be a result of employee beliefs that it is some kind of responsibility to stay in the organization, feeling of obligation to remain in the organization.

Table (6) : Overall Statistical Descriptive of Organizational commitment

\begin{tabular}{|c|c|c|c|c|c|c|c|}
\hline \multirow{2}{*}{ The variable } & \multirow{2}{*}{ Mean } & \multirow{2}{*}{ SD } & \multicolumn{5}{|c|}{ Frequencies (\%) } \\
\cline { 4 - 8 } & & & $\mathbf{1}$ & $\mathbf{2}$ & $\mathbf{3}$ & $\mathbf{4}$ & $\mathbf{5}$ \\
\hline $\begin{array}{c}\text { Organizational } \\
\text { commitment }\end{array}$ & 2.98 & 1.17 & 16.7 & 20.5 & 25.44 & 22.9 & 14.41 \\
\hline
\end{tabular}

Finally, as shown in table (6) the mean value of the overall variable of Organizational commitment variable is (2.98); this value indicates that the respondents were neutral about the variable, which means that, the respondents are moderately committed to their companies. 
3.3Verifying the Study Hypotheses:

\subsubsection{The relationship between transformational leadership and} organizational commitment

The following table investigates the correlation between the independent variables and the dependent variable

Table (7) the relationship between transformational leadership and organizational commitment

\begin{tabular}{|c|c|c|c|c|}
\hline & $\begin{array}{c}\text { Organizational } \\
\text { commitment }\end{array}$ & $\begin{array}{c}\text { Normative } \\
\text { Commitment }\end{array}$ & $\begin{array}{c}\text { Continuance } \\
\text { Commitment }\end{array}$ & $\begin{array}{c}\text { Affective } \\
\text { Commitment }\end{array}$ \\
\hline Idealized influence & $.396^{* *}$ & .086 & .094 & $.370^{* *}$ \\
\hline $\begin{array}{c}\text { Inspirational } \\
\text { motivation }\end{array}$ & $.414^{* *}$ & $.294^{* *}$ & $.126^{*}$ & $.379^{* *}$ \\
\hline Intellectual stimulation & $.292^{* *}$ & $.157^{* *}$ & .037 & $.260^{* *}$ \\
\hline $\begin{array}{c}\text { Individual } \\
\text { consideration }\end{array}$ & $-.247^{* *}$ & $.109^{*}$ & $.142^{* *}$ & $-.282^{* *}$ \\
\hline $\begin{array}{c}\text { Transformational } \\
\text { leadership style }\end{array}$ & $.388^{* *}$ & $.131^{* *}$ & .025 & $.372^{* *}$ \\
\hline
\end{tabular}

**. Correlation is significant at the 0.01 level (2-tailed).

*. Correlation is significant at the 0.05 level (2-tailed).

From the previous table, there is a significant correlation between the transformational leadership style scale and the organizational commitment dimension (the correlation value $=0.388$ and, correlation is significant at the 0.01 level) in the form of a moderate inverse correlation. This finding is consistent with the studies of (Blankenship, 2010; Bushra et al. 2011; Kim et al., 2012; Kathleen, 2013; Salem, 2013; Swindell, 2014; Njoroge, 2015; Rossington, 2015; Gulluce et al., 2016; Lim, 2016; Naktiyok \& Yekeler, 2016; Patiar \& Wang, 2016; Triana et al., 2016).

\subsubsection{The influence of transformational leadership on organizational commitment}

Table (8) The influence of transformational leadership on organizational commitment

\begin{tabular}{|c|c|c|c|}
\hline The independent variable & B & T & P-Value \\
\hline Idealized influence & 1.598 & 5.975 & 0.000 \\
\hline Inspirational motivation & 1.028 & 6.736 & 0.000 \\
\hline intellectual stimulation & .802 & 4.487 & 0.002 \\
\hline Individual consideration & -.470 & -4.456 & 0.000 \\
\hline Transformational leadership style scale & -2.991 & -5.318 & 0.000 \\
\hline F significant & F & \multicolumn{2}{|c|}{$\mathbf{R 2}$} \\
\hline 0.000 & 26.370 & \multicolumn{2}{|c|}{0.69} \\
\hline
\end{tabular}


From the previous table, the coefficient of determination is equal to $69 \%$ and this shows that the dimensions of transformational leadership succeeded in explaining changes in the organizational commitment as a whole increased by $69 \%$. As evidenced by the previous table that form as a moral value moral test $\mathrm{F}$ less than 0.05 .

Also, there is a statistically significant positive moral impact of scale effect on organizational commitment scale ideal as a whole as the test value less than0.05. That indicates that the scale of the ideal impact positively on organizational commitment scale.

\subsection{Verifying the Study Hypotheses:}

To test the study Hypothesis that said, "There is significant relationship between transformational leadership and organizational commitment of airlines' employees". The study hypothesis was accepted".

\section{Conclusions}

This research highlights the importance of transformational leadership style and its relation to organizational commitment components by examining the statistical relationship between the two variables. Empirical research was conducted on a sample of 407 employees. The data collected has been classified and tabulated to be thoroughly. The study employed a questionnaire as an instrument for data collection.

To achieve the study objectives the researcher used two scale measurements The Multifactor Leadership Questionnaire and The Organizational Commitment Scale (Avolio \& Bass, 2004). All the questionnaire forms were distributed from March to June 2017.

The researcher has calculated the necessary percentages and formed the frequencies tables using one of the most important descriptive statistical techniques in identifying and defining the research variables and their response rates with drawn sample.

The results of testing hypotheses revealed that there is a significant relationship between the transformational leadership and the organizational commitment of the airlines' employees.

\section{Recommendations}

Based on the findings of this study, a number of recommendations can be formulated as recommendations to airline companies:

1- Leaders should set plans to enhance employees' participation in decision making, encourage them to share their aims, targets, visions and goals, cause them to distinguish with their leaders, unite employees with management and stimulate team spirit.

2- Leaders should take their employees opinions in consideration, attend to followers' needs and listen to their concerns, treat each one as an individual with unique needs and consider individual differences. 
3- In order to raise the employees' level of organizational commitment transformational leaders should try to make the better use of the overall working circumstances, performance appraisal, working environmental conditions, work practice in recruitment or selection and also working relationships.

4- Leaders in aviation industry should re-examine their strategies to emphasize the organizational commitment via various means including lectures, seminars and training workshops.

\section{References}

- Afşar, S. (2014). Impact of the Quality of Work-life on Organizational Commitment: A Comparative Study on Academicians Working for State and Foundation Universities in Turkey, International Journal of Social Sciences. 3(4): 124-152.

- Ahmad, F. Abbas, T. Latif, S. and Rasheed, A. (2014). Impact of Transformational Leadership on Employee Motivation in Telecommunication Sector. Journal of Management Policies and Practices. 2 (2): 11-25.

- Ahmad, N. Iqbal, N. Javed, K. and Hamad, N. (2014). Impact of Organizational Commitment and Employee Performance on the Employee Satisfaction. International Journal of Learning, Teaching and Educational Research. 1(1): 84-92.

- Aliakbari, M. and Darabi, R. (2013). On The Relationship between Efficacy of Classroom Management, Transformational Leadership Style, and Teachers' Personality. 3rd World Conference on Learning, Teaching and Educational Leadership - WCLTA 2012, Procedia Social and Behavioral Sciences. 93: 1716 - 1721.

- Allameh, S. and Davoodi, S. (2011). Considering transformational leadership model in branches of Tehran social security organization. Procedia Social and Behavioral Sciences. 15: 3131-3137.

- Allen, N. J., and Meyer, J. P. (1990). The measurement and antecedents of affective, continuance and normative commitment to the organization, Journal of Occupational Psychology, 63, 1-18.

- Ann, O. (1993). The relationship between transformational leadership and employee loyalty, employee commitment, and employee perceptions of organizational justice. PhD Thesis. Michigan State University.

- Anttila, E. (2014). Components of Organizational Commitment A case study consisting line managers from Finnish industrial company. MSc thesis. University of Tampere, School of Education.

- Avolio, B. and Bass, B. (2004). Multifactor leadership questionnaire: Manual and sampler set. Menlo Park, CA: Mind Garden.

- Baek, J. (2012). The Impact of Transactional and Transformational Leadership on Organizational Commitment in Major League Baseball. Master Thesis. St. Thomas University. 
- Banks, G. McCauley, K. Gardner, W. and Guler, C. (2016). A metaanalytic review of authentic and transformational leadership: A test for redundancy. The Leadership Quarterly. 27(4): 634-652.

- Bass, B. (1985). Leadership and performance beyond expectations. New York: Free Press.

- Bass, B. and Avolio, B. (1994). Improving organizational effectiveness through transformational leadership. CA.Sage Thousand Oaks.

- Bass, B. M. (1990). From transactional to transformational leadership: Learning to share the vision. Organizational dynamics, 18(3), 19-31.

- Bill, L. (2010). Transformational leadership and organizational commitment: A study of UNC system business school department chairs. $\mathrm{PhD}$ thesis. Capella University.

- Blankenship, S. (2010). The consequences of transformational leadership and/or transactional leadership in relationship to job satisfaction and organizational commitment for active duty women serving in the Air Force Medical Service. PHD thesis. Nova Southeastern University.

- Bowling, A. (1997) Research Methods in Health. Open University Press, Buckingham.

- Bozlagan, R. Dogan, M. and Daoudov, M. (2010). Organizational commitment and case study on the union of municipalities of Marmara. Regional and Sectoral Economic Studies. 10(2): 29-57.

- Buchanan, B. (1974). Building organizational commitment: The socialization of managers in work organizations. Administrative science quarterly, 22:533-546.

- Burns, J. (1978). Leadership. New York: Harper \& Row New York.

- Bushra, F. Usman, A. and Naveed, A. (2011). Effect of Transformational Leadership on Employees' Job Satisfaction and Organizational Commitment in Banking Sector of Lahore (Pakistan). International Journal of Business and Social Science. 2(18): 261-267.

- Cetin, M. and Kinik, S. (2015). An analysis of academic leadership behavior from the perspective of transformational leadership. 11th International Strategic Management Conference, Procedia - Social and Behavioral Sciences. 207: 519-527.

- Chao, H. An, Q. and Lin, P. (2016). Transformational Leadership, Psychological Capital and Front-line Sales Staffs' Service Quality: Psychological Capital as a Mediator. International Journal of $u$ - and eService, Science and Technology. 9(7): 309-316.

- Chatterjee, A. and Kulakli, A. (2015). An Empirical investigation of the relationship between Emotional Intelligence, Transactional and Transformational Leadership Styles in banking sector. 4th International Conference on Leadership, Technology, Innovation and Business Management, Procedia - Social and Behavioral Sciences. 210: 291-300. 
- Colquitt, J. (2006). Transformational leadership and job behaviors: the mediating role of core job characteristics. Academy of Management Journal. 49(2): 327-340.

- Contractor, S. (2016). The Role of Transformational Leadership in Organizational commitment. Sai Om Journal of Commerce \& Management. 3(1): 1-4.

- De Vos, A. Strydom, H. Fouche, C. and Delport, L. (2005). Research at grassroots for the social sciences and human service professions. (3rd Ed.). Pretoria, S.A. Van Shaik.pp.222-223.

- Ebrahimi, P. Moosavi, S. and Chirani, E. (2016). Relationship between Leadership Styles and Organizational Performance by Considering Innovation in Manufacturing Companies of Guilan Province. 3rd International Conference on New Challenges in Management and Organization: Organization and Leadership. Procedia - Social and Behavioral Sciences. 230: 351-358.

- El Gamal, M. (2009). The Role of Emotional Intelligence and Transformational Leadership in fostering Employee Organizational Citizenship Behavior in International Organizations (Applied on Wadi Degla-Egypro Holding Company). Master Thesis. Sadat Academy for Management sciences.

- El-marad, H. (2005). Impact of transformational leadership behavior on trends in working towards change applied study on Syrian Arabic aviation Foundation. Faculty of Commerce Ain Shams University. (in arabic).

- Freiberg, K. (1987). The heart and spirit of transformational leadership: a qualitative case study of Herb Kelleher's passion for Southwest Airlines. University of San Diego. California.

- Gandhi, I. and Hyde, A. (2013). Organizational Commitment in Nationalized Banks. Pacific Business Review International. 6(5): 58-68.

- Gulluce, A. Kaygin, E. Kafadar, S. and Atay, M. (2016). The Relationship between Transformational Leadership and Organizational Commitment: A Study on the Bank Employees. Journal of Service Science and Management. 9: 263-275.

- Indrawati, N. (2014). Management by Inspiration: Implementation of Transformational Leadership on Business at Pondok Pesantren*) Sunan Drajat. The 5th Indonesia International Conference on Innovation, Entrepreneurship, and Small Business, Procedia -Social and Behavioral Sciences. 115: 79-90.

- Irefin, P. and Mechanic, M. (2014). Effect of Employee Commitment on Organizational Performance in Coca Cola Nigeria Limited Maiduguri, Borno State. IOSR Journal of Humanities and Social Science. 19(3): 3341.

- Jacob, J. (2015). An empirical investigation of the transformational leadership traits between employees of federal, state and local governments in the United States. Master thesis. Capella University. 
- Jong Hun, B. (2012).The Impact of Transactional and Transformational Leadership on Organizational Commitment in Major League Baseball. EdD thesis. St. Thomas University.

- Jung, D. Chow, C. and Wuc, A. (2003). The role of transformational leadership in enhancing organizational innovation: Hypotheses and some preliminary findings. The Leadership Quarterly. 14: 525-544.

- Kala'lembang, A. Soetjipt, B. and Sutrisno, (2015). The Effect of Transformational Leadership and Organizational Culture on Employee's Working Performance through Organizational commitment. I J A BER. 13(7): 5305-5322.

- Kathleen, M. (2013). A Meta-Analysis of Transformational Leadership and Subordinate Nursing Personnel Organizational Commitment, Job Satisfaction, and Turnover Intentions. $\mathrm{PhD}$ thesis. University of Maryland, Baltimore.

- Khan, I. Nawaz, A. and Khan, M. (2013). Determining the Organizational Commitment of Academicians in Public Sector Universities of Developing Countries like Pakistan. International Journal of Academic Research in Accounting, Finance and Management Sciences. 3(1): 280-289.

- Kim, S. Magnusen, M. Andrew, D. and Stoll, J. (2012). Are Transformational Leaders a Double- Edged Sword? Impact of Transformational Leadership on Sport Employee Commitment and Job Satisfaction. International Journal of Sports Science \& Coaching. 7 (4): 661-676.

- Kowalczyk, D. (2015). Convenience Sample: Example \& Definition. Retrieved from http://study.com/academy/lesson/convenience-sampleexample-definition-quiz.html

- Lim, C. S. (2016). An investigation of leadership styles and leadership outcomes of Malaysian managers working in the wholesale subsector of the distributive trade sector. DBA thesis. Southern Cross University, Australia, Lismore, NSW.

- Liu, P. (2013). Motivating Teachers' Commitment to Change by Transformational School Leadership in Urban Upper Secondary Schools of Shenyang City, China. PHD Thesis. Ontario Institute for Studies in Education, University of Toronto.

- Longwell-McKean, P. (2012). Restructuring leadership for 21st century schools: how transformational leadership and trust cultivate teacher leadership. Master Thesis. University of California-San Diego.

- Lumley, E. J. (2008). Exploring the relationship between career anchors, job satisfaction and organizational commitment. $\mathrm{PhD}$ thesis. University of South Africa, Pretoria.

- Madi, M. Abu-Jarad, I. and Alqahtani, A. (2012). Employees' Perception and Organizational Commitment: A Study on the Banking Sector in Gaza, Palestine. International Journal of Business and Social Science, 3(16): 301. 
- Marla J. and Weston, R. (2008). Transformational Leadership at a National Perspective. Nurse Leader. 41-50.

- Meyer, J. Allen, N. (1997).Commitment in the workplace: Theory, research and application. CA: Sage, Thousand Oaks.

- Meyer, J. and Allen, N. (1991). A three-component conceptualization of organizational commitment. Human Resource Management Review. 1(1): 61-89.

- Mohamed, L. (2016). Assessing the effects of transformational leadership: A study on Egyptian hotel employees. Journal of Hospitality and Tourism Management. 27: 49-59.

- Nahavandi, A. (2016). The Art and Science of Leadership -Global Edition. Pearson.

- Naktiyok, A. and Yekeler, K. (2016). The role of transactional leadership behavior on the effect of transformational leadership on organizational commitment: A case of a public institution. Amme Idaresi Dergisi. 49 (2): 105-143.

- Nickson, D. (2013). Human resource management for hospitality, tourism and events. Routledge.

- Njoroge, D. (2015). Transformational Leadership Style and Organizational commitment: The Moderating Effect of Employee Participation. Strategic Journals. 2 (6): 94-107.

- Pallant, J. (2010). SPSS survival manual: A step by step guide to data analysis using SPSS. New York, NY: McGraw-Hill.

- Patiar, A. Patiar, A. Wang, Y. and Wang, Y. (2016). The effects of transformational leadership and organizational commitment on hotel departmental performance. International Journal of Contemporary Hospitality Management. 28(3): 586-608.

- Qassem, M. (2012). A three dimension model for the relationship among quality of work life, organizational commitment and job involvement " $a$ field study on civil employees of the ministry of interior". PHD thesis, Ain-shams University.

- Rehman, S. Shareef, A. Mahmood, A. and Ishaque, A. (2012). Perceived Leadership Styles and Organizational commitment. Interdisciplinary Journal of Contemporary Research in Business. 4(1): 616-626.

- Rossington, S. (2015). The propensity to pursue executive coaching: Variables of self-efficacy and transformational leadership. Doctoral Dissertation, Capella University.

- Rothfelder, K. Ottenbacher, M. and Harrington, R. (2012). The impact of transformational, transactional and non-leadership styles on employee job satisfaction in the German hospitality industry. Tourism and Hospitality Research. 12(4): 201-214.

- Salem E. (2013). Studying the relationship between transformational leadership and: on five stars hotels in Egypt. Master thesis. Alexandria University. 
- Seppänen, A. (2012). Perceptions of Perceived Organizational Support and Affective Organizational Commitment in Radisson Blu Seaside. Thesis Degree. University of Applied Sciences.

- Sharma, P. Nagar, P. and Pathak, S. (2012). Impact of Transformational Leadership on Creative Flexibility of Engineers in India. ProcediaSocial and Behavioral Sciences. 57: 555-559.

- Stokes, D. (2013). Exploring the relationship between cultural intelligence, transformational leadership, and burnout in doctorate of education students. Liberty University. Doctoral Dissertation. Liberty University.

- Swindell Jr, J. R. (2014). Transformational leadership, perceived support, organizational commitment, and union citizenship behavior: The effect of cultural diversity. Doctoral dissertation. Indiana Institute of Technology.

- Tabachnick, B. G., and Fidell, L. S. (2007). Using multivariate statistics ( $5^{\text {th }}$ ed.). Boston: Pearson.

- Triana, M. Richard, O. and Yücel, I. (2016). Status Incongruence and Supervisor Gender as Moderators of the Transformational Leadership to Subordinate Affective Organizational Commitment Relationship. Personnel Psychology.

- Veal, A. J. (2006). Research methods for leisure and tourism: A practical guide. Pearson Education.

- Wahab, S. Rahmat, A. Yusof, M. and Mohamed, B. (2016). Organization Performance and Leadership Style: Issues in Education Service. 6th International Research Symposium in Service Management, IRSSM-6 2015, 11-15 August 2015, UiTM Sarawak, Kuching, Malaysia,Procedia - Social and Behavioral Sciences. 224: 593-598.

- Yates, K. (2013). Measuring Transformational Leadership in Athletic Training: A Comparative Analysis. PHD thesis. University of Kentucky: 23.

- Zhu, W. Newman, A. Miao, Q. and Hooke, A. (2013). Revisiting the mediating role of trust in transformational leadership effects: Do different types of trust make a difference?. The Leadership Quarterly. 24(1): 94-105.

- Zikmund, W. (2003). Business research methods. Singapore: Thomson Learning.

- The annual bulletin of air transport statistics (2015), Central Agency for Public Mobilization and Statistics (CAPMAS). 


\title{
أثر القيادة التحويلية علي الالتزام التنظيمى للموظفين بثركات الطيران المصرية
}

\author{
الملخص العربي
}

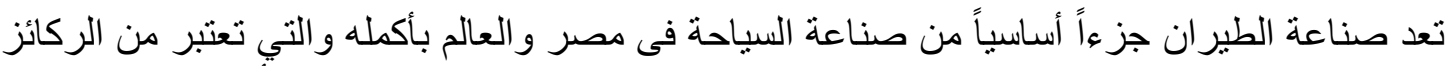

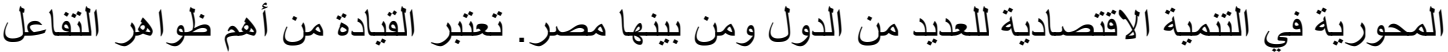
الاجتماعي، لأن القادة يؤثرون في توجيه نشاط الجماعة وفي مدى إنتاجها و الروح السائدة بين أفرادئ الدها.

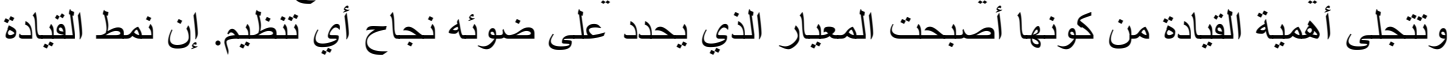

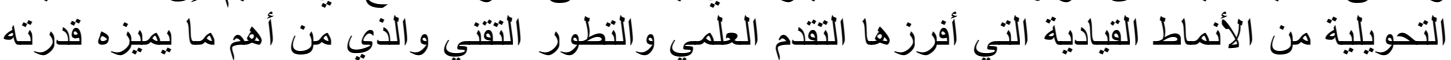

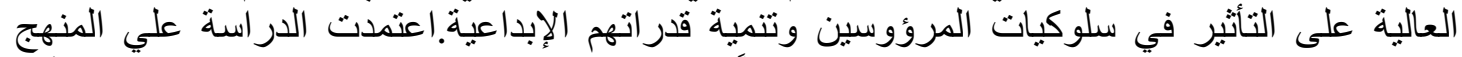

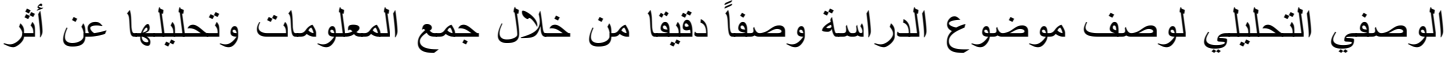

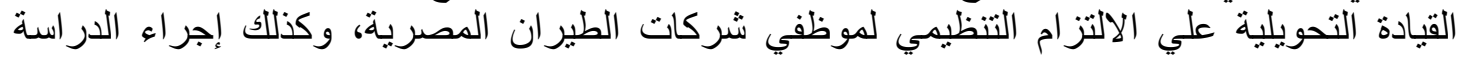

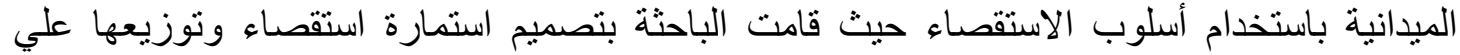
موظفي شركات الطيران المصرية المختلفة خلال فترة الدراسة، وتم اختيار عينه الدراسة الذي الذي تم

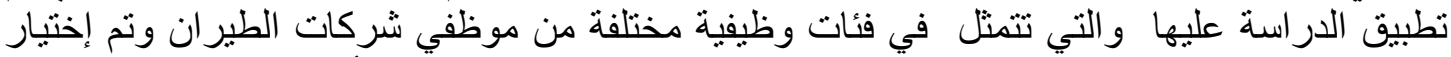

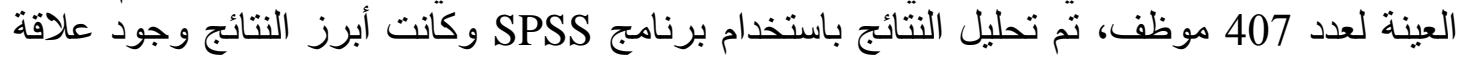

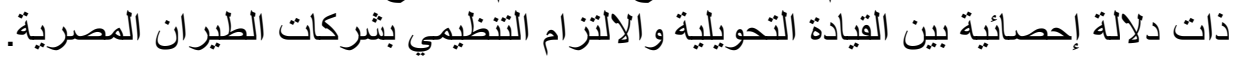

الكلمات الدالة: القيادة التحويلية، الالتز ام التنظيمي، شركات الطيران، مصر. 